\title{
AN IMPACT OF PANDEMIC COVID-19 ON INDIAN AGRICULTURAL SECTOR.
}

\author{
Balasaheb Kalhapure \\ Commerce SKM College Shirwal, Tal-Khandala, Dist-Satara. \\ Email: kalhapurebb@rediffmail.com
}

\begin{abstract}
:
COVID-19 pandemic has disrupted the Indian agricultural farming sector extensively. Nevertheless, the recent quarterly GDP estimates post-COVID scenario showcase robustness and resilience in Indian agriculture, the sole sector to register a positive growth of three.4\% during the twelvemonth (FY here after) 2020-21 (Quarter 1: April 2020 to June 2020). At the identical time, the immediate past quarter growth was estimated at $5.9 \%$ witnessing a decline by $2.5 \%$ point. during this context, we aim to synthesize the first evidence of the COVID-19 impact on the Indian agricultural Farming sector viz., framers, labor,production, marketing and consumption followed by a group of potential strategies to recover and prosper post-pandemic. Survey findings indicate that the pandemic has affected farmer, production and marketing through labor and logistical constraints, while the negative income shock restricted access to markets and increased prices of food commodities affecting the consumption pattern. The pandemic wreaked a considerable physical, social, economic and emotional havoc on all the stakeholders of Indian agricultural farming. Seizing the crisis as a chance, the state announced a raft of measures and long-pending reforms. We propose some point strategy starting from social safety nets, family farming, monetizing buffer stock, staggered procurement to secondary agriculture to revive and prosper post-pandemic.
\end{abstract}

\section{INTRODUCTION:}

As the world comes to a halt and public, social life shuts down across the globe; We're all have their eyes on the healthcare systems which are buckled under the strain of the COVID-19 murrain. With the lockdown period anticipated to extend for some another time, there are now concerns rising over food inventory and people are now frightened. The implicit negative impacts of germicide Corona-19 on India 's agrarian output, demand stability, food inventory may now be seen from the outside but it's still problematic to foretell quantify the exact damage verbatim. Notwithstanding, viewing the current screenplay and hung on the floating news, presently an overview of the impact on agrarian output and penny-pinching.
Everyone around the world likely knows that farming diligence is one of the most inconsistent sectors. This principle seems to go yea verily now. Agriculture Farmers, Labor, food processors, retailers and fair all stakeholders of the farming sector now wonder what's coming next. How much should they're produce to meet summer demand? What should they do with the stocks and losses? How will be family cultivators survive? How much should they deal and to whom? Multicolored screenplays are fantasized in the surveyed essays, from fast recovery to a long- eternal crunch. Everything depends on the length of the ailment. Outside governments of the world have now launched some ad-hoc measures as part of a "fire- gang policy- making" to attack the movables of the inaugural shock. Notwithstanding, these first 
replies led to stockpiling comportment at the home level. However, these labors will surely not be enough, If the affection lasts for multifold another month. Medium-and long- term "parsimony survival" programmes are about to be developed to manage long- term goods, including those impacting farming.

It's ostensive that the COVID-19 affection turned the world upside down, including farming. Much another work is now claimed from motley scientists working in the different fields to analyses the goods. In the current situation when long- term data aren't yet available, this ideal paper might serve as a background for unborn probing in stressing the fields of global interest in husbandry and related sectors.

As a limitation of the study, note that our analyses are rested on English- language results only, which, on the one hand is suitable and, on the other hand, poses some bias. It would have been an endless exercise to delve compositions in all languages of the world. Although regional issues can also be important, we allow that all major global issues raised in the period anatomized are covered by our hunt and results

\section{OBJECTIVES OF STUDY:}

1. To evaluated modifications inside the agriculture farming practices in reaction to the pandemic.

2. To decide the impact of the coronavirus pandemic on the Agriculture Farmers, labor.

3. To evaluate the issues will rise up within the lives of farmers and agricultural people.

\section{RESEARCH METHODOLOGY:}

The evaluation paper is based definitely on the Secondary records. it's miles analyses available literature on Agriculture Farming Sector in mainly Rural and concrete vicinity. The Secondary facts regarding the study changed into received from the various journals, books, Magazines, Newspapers and websites. Our records series trusted interviews with key stakeholders inner and helping the Agriculture Farmers and hard work. Interviews were done face to face and virtually over the mobile tele cellular smartphone and thru what Sapp. Questions can be discovered within aspect the appendices.

\section{IMPACT OF COVID-19 ON THE INDIAN AGRICULTURAL SECTOR PRODUCTION, MARKETING AND CONSUMPTION:-}

The hand-picked rabbi crop that time was standing well in the field. The field has been harvested but no labor is available. All transactions have come to a standstill due to the lockout. In fact, this is the season for planting black pepper, coffee and banana. However, it also seems to be wasted. The rabi crop season has been disrupted due to the lockout. Labor has been lost, harvesters, threshers, tractors, freight have been stopped, and movement of people has been banned. Producers of perishable crops like fruits, vegetables and flowers have lost money. Their goods do not rise. They have to sell the goods at hand to Kavadimol Bhav.(to Sale Agro product less price mean minimum price/rate .)

Brokers or brokers are taking advantage of this situation. In fact, it is the harvest season for flowers. Many small farmers in Tamil Nadu grow flowers as a cash crop. However, in the given situation, they also have to bear the loss. Had it been for the Corona-free situation, these same farmers would have earned millions from floriculture. The lockout has also affected crop cultivation in Kerala and Tamil Nadu. Due to lack of transportation

Fishermen have been harassed by the closure of maritime transport, restrictions on trade, 
restrictions on movement. Trade in mussels exported to Europe and the United States has stalled, and demand for fish in the local market has dwindled, leaving fishermen without a ghost or future.

The tribal people have suffered the most from the ban. This is because the tribal people are among the most vulnerable communities in terms of food and nutrition security. Along with forest products, the two main occupations of the tribal are collecting leopard leaves and plucking moha flowers. They get a lot of income from it. However, due to the ban, the tribals in Odisha have to bear the brunt. Because no agent has come to Yeinasa to take Moha flowers and Tendu leaves from them and the local markets are also closed.

In rural India, borrowing is a common practice. It is repaid by borrowing from a large lender at a high interest rate. There are signs that similar loans will be used to overcome the situation. It is reported that lenders are giving loans to farmers at $24 \%$. Even the poorest farmers are taking loans on the promise of repaying these loans after the harvest season. However, as perishable goods are not available in the market and are being sold in the local market at inflated prices, farmers are facing financial losses and large instalment's of loans.

The central government has given some concessions to the agricultural sector through lockout. Restrictions on trade in agricultural commodities and fish were lifted by the central government at the end of March. However, these concessions have not reached the farmers due to lack of coordination on actual land conditions. Many media outlets have pointed out that there are many difficulties in getting government aid to the poor and needy. Local self-government organizations as well as NGOs are in the forefront in providing emergency assistance to the needy.
To give an example, M. S. Swaminathan Research Foundation. This organization has given a helping hand to the distressed farmers with the help of technology. Activities such as advising farmers on crop cultivation, organizing agricultural programs through phone-in, guiding and assisting in the sale of agricultural commodities are being implemented by this organization with the help of Farmers Producers Association. The organization has also raised awareness about corona and provided guidance in many villages on what measures should be taken to avoid it.

On April 15, the central government has extended the lockout till May 3. The Union Home Ministry has issued some guidelines for extending the lockout period. Accordingly, the lockout has relaxed restrictions on agriculture, floriculture, animal husbandry, poultry and fishing, and transactions related to these businesses. Workers can go to work, markets can be opened, purchases can be made, agroprocessing industries as well as agri-shops can be kept open. Work on the Mahatma Gandhi National Rural Employment Guarantee Scheme will also be launched soon. These guidelines were adopted to give a boost to the rabbi season of the farmers and to enable the farmers to make arrangements for kharif crops. Now it needs to be properly implemented.

Many problems will arise in the lives of farmers and agricultural laborers after getting relief from the crisis. Migrant workers who fled their homes after 21-day layoffs and those who returned home safely are unlikely to return to work immediately. Many of them may not even be eager to return to the city. The number of such can be large. Therefore, both relief and rehabilitation measures will be needed.

By building confidence in migrant workers, building trust in the government, they will have to be prepared to return to work. Only then will 
their employment survive and alternatively the family that depends on them!

As long as the corona continues, social distance and hand washing will continue to be followed. Some initiatives are expected to be implemented voluntarily by the state governments. State governments have an important role to play in building confidence in the underprivileged. Care should be taken to ensure that more relief work is done for them (e.g. opening the ration system to all.)

Administrative hurdles like ration cards will also have to be put aside.). Cash will also have to be provided (e.g., the current limit of PM Kisan Nidhi has to be increased from Rs 6,000 to Rs 15,000 and efforts will be made to ensure that this amount reaches farmers before the kharif season), lenders will have to be curbed, Deferment of interest on MSME loans for three months, compensation for loss of perishable goods like fruits-vegetables-flowers and fish, removal of various works under Mahatma Gandhi National Rural Employment Guarantee Scheme to provide employment to more people, encourage agricultural laborers to work in the fields Etc. Of course, the central government will have to work with the state governments to revive the rural economy by planning measures

\section{SUGGESTION:}

There's an occasion moment to not just respond effectively to the current Dunkirk, but to roll back distortive, ineffective and environmentally evil support, thereby freeing up monetary finances for investments in a more productive, sustainable and springy food system fit to meet new challenges. This, together with accompanying directorial reforms, can help make enabling environs for the entire Farming sector food system that's aligned with natural resource limits, a changing climate, demand, technological developments, and "low probability, high impact" disastrous menaces. The unexpected shock of COVID-19 underscores the need for a shift from "business as usual" methodologies to a more forwardlooking policy package that invests in the productivity, sustainability, and the plasticity of the global food system.

1. Guaranty that support measures intended to give temporary relief to cultivators and other food system stakeholders are concordant with wider socio- money-spinning methodologies, reach vulnerable socio- money-spinning groups and contain clear exit strategies.

2. Consider wider occasions to repurpose agrarian support in ways that give clear public goods, in particular in the form of climate change mitigation and enriched environmental fates.

3. Continue troubles to piece and maintain mechanisms to ice lucency and policy dialogue on food systems, parallel as AMIS, to piece confidence in global requests and co-operation.

4. In moving forward, consider how taking on an unmixed approach can help assure the limberness of the global food system. With enhanced limberness the food system will be better capable to deliver on the threefold challenge delivering safe, affordable food for a growing world population and livelihoods for the beaucoup people involved in food around the world (including the adulthood of the world 's poor who live in bucolic areas), while assuring environmental sustainability in the face of complex environmental challenges and a climate boiling point.

\section{CONCLUSION:}

In COVID-19 pandemic has a great impact on the address and conditioning of humanity; farming isn't outside this impact. Agriculture 
Farmers, Labor, Food demand and so food security are greatly affected due to mobility restrictions, reduced Productivity and buying power, and with a primary impact on the most vulnerable population groups. As cases of contagion increase, governments take added drastic measures to stop the spread of the disease, also impacting the global food system. The premise of any measure embraced should be to defend the health and food security of the population, to the detriment of gainful growth, although some governments go in the diametric direction.

The farming value chain in India has been hypercritically affected by the Covid-19 boiling point and the attendant lockdown. Farming remains a central pillar of the Indian frugality. The sector serves the food consumption demands of the whole country, while also placing among the top exporters of agrarian labor in the world. The agriculture sector has been facing its share of challenges in recent eras, but multiple have been as severe as the domestic and multinational passage restrictions during Covid-19.

\section{REFERENCES:}

Huber, M.,2003. Environ. Sci. Technol. 37, 10161024.

Susmita A. Mandavgane; Study of degradation of p-toluic acid by photo-oxidation, peroxidation, photo-peroxidation and photofenton processes; Materials Today: Proceedings 29 (2020) 1213-1216.

Arun, MG (2020) Critical but stable. New Delhi. Available at: https://www.indiatoday.in/magazine/natio $\mathrm{n} /$ story/20200817-critical-but-stable1708696-2020-08-08 (accessed 28 August 2020).

Carberry, P, Padhee, AK (2020) Containing COVID 19 impacts on Indian agriculture.
Available

at:

https://www.icrisat.org/containing-

covid19-impacts-on-indian-agriculture

(accessed 30 August 2020).

Cariappa, AGA, Acharya, KK, Adhav, CA, et al. (2020a) Pandemic led food price anomalies and supply chain disruption: evidence from COVID-19 incidence in India. SSRN. DOI: $10.2139 /$ ssrn.3680634.

Chengappa, PG (2013) Secondary agriculture: a driver for growth of primary agriculture in India. Indian Journal of Agricultural Economics 68(1):1-19.

Dev, SM (2020) Addressing COVID-19 impacts on agriculture, food security, and livelihoods in India. Available at: https://www.ifpri.org/blog/addressingcovid-19-impacts-agriculture-food-securityand-livelihoods-india (accessed 30 August 2020).

Dey, K (2019) Secondary agriculture: the shift Indian farming needs. Available at: https://www.financialexpress.com/opinion / secondary-agriculture-the-shift-indianfarming-needs/1807044/ (accessed 30 August 2020).

Government of India (2020a) Agriculture and Food Management. Economic Survey 201920, Ministry of Finance. Available at: https://www.indiabudget.gov.in/economics urvey/doc/vol2chapter/echap07_vol2.pdf (accessed 30 August 2020).

Government of India (2020b) PIB Press Release 3 June 2020. Available at: https:/ / pib.gov.in/PressReleasePage.aspx? PRID=1629033 (accessed 30 August 2020).

Gulati, A (2020) Offloading excess food grain stocks through open market operations will generate much-needed resources for govt. Available at: https://indianexpress.com/article/opinion /columns / india-lockdown-food-stock-food- 
corporation-of-india-ashok-gulati-

6469970/ (accessed 1 September 2020).

Imbert, C (2020) Webinar on inter-state migration in India in the time of COVID-19. India. Available at: https://www.youtube.com/watch?v=XdVp2 S4-hgQ (accessed 9 September 2020).

Kalsi, SS, Sandoval, L, Sood, D (2020) COVID-19 in India - Trade Situation Update Report Highlights. Report No. IN2020-0017.

Narayanan, S, Saha, S (2020) Urban food markets and the lockdown in India. SSRN Electronic Journal 1-25. DOI: 10.2139/ssrn.3599102.

Padhee, AK, Pingali, P (2020) Lessons from a pandemic to repurpose India's agricultural policy. Nature India. May. DOI: 10.1038/nindia.2020.83 (accessed 15 July 2020).

Sendhil, R, Ramasundaram, P, Subash, SP, et al. (2020a) Policy imperatives for wheat procurement. Policy Paper 1. ICAR-Indian Institute of Wheat and Barley Research, Karnal, Haryana, India. DOI: 10.13140/RG.2.2.13542.65604/1.

Timilsina, B, Adhikari, N, Kafle, S, et al. (2020) Addressing impact of COVID-19 post pandemic on farming and agricultural deeds. Asian Journal of Advanced Research and Reports 11(4):28-35.

Varshney, D, Roy, D, Meenakshi, JV (2020) Impact of COVID-19 on agricultural markets: assessing the roles of commodity characteristics, disease caseload and market reforms. Indian Economic Review 55:83-103.

GOI. (2019) National Accounts Statistics-2019, Central Statistical Organization. Government of India, New Delhi.

DAHD. (2020) 20th Livestock Census-2019 All India Report. Department of Animal Husbandry and Dairying Ministry of Fisheries Animal Husbandry and Dairying, Government of India, New Delhi, p119.

DAHDF. (2019) Annual Report 2018-19. Department of Animal Husbandry, Dairying and Fisheries. Ministry of Agriculture and Farmers Welfare, government of India, New Delhi. p192.

Jaganmohan, N. (2020) Consumption Volume of Poultry Meat in India from 2013 to 2019. Statista. Available from: https://www.statista.com/statistics / 82671 $1 /$ indiapoultry-meat- consumption. Retrieved on 12-07-2020.

Shukla, P.K. and Bhattacharyya, A. (2020) Impact of COVID-19 on Indian Poultry Sector. Poultry Punch Magazine. Available from: https://www.thepoultrypunch. com/2020/05/impact-of-COVID-19-onindian-poultry-sector. Retrieved on 12-072020.

Suresh, A. and Reddy, A.A. (2020) Reinventing Agriculture in the Time of COVID-19. The WIRE. Available from: https://www.thewire.in/agriculture/reinve nting-agriculturein-the-time-of-COVID-19. Retrieved on 25-04-2020 